\title{
PENINGKATAN HASIL BELAJAR DENGAN MENGGUNAKAN METODE PEMBELAJARAN STUDENT TEAM LEARNING MODIFICATION
}

\author{
Nurfaidah $^{(1)}$, Suprapta $^{(2)}$, Muh. Said L ${ }^{(3)}$ \\ (1) Fakultas Tarbiyah dan Keguruan UIN Alauddin Makassarnurfaidahphysic@gmail.com \\ (2)Fakultas MIPA Universitas Negeri Makassar suprapta21@gmail.com \\ (3) Fakultas Sains dan Teknologi UIN Alaudddin Makassar muhammadsaidlanto83@gmail.com
}

\begin{abstract}
Abstrak
Masalah penelitian ini adalah seberapa besar hasil belajar siswa dengan menggunakan metode pembelajaran student team learning modification, seberapa besar hasil belajar siswa tanpa menggunakan metode pembelajaran student team learning modification, dan 3. Apakah terdapat peningkatan hasil belajar siswa setelah diajar dengan menggunakan metode pembelajaran student team learning modification, dengan menggunakan teknik purposive sampling diperoleh sampel sebanyak sebanyak 31 siswa. Teknik analisis data yang digunakan yaitu analisis data statistik deskriptif. Hasil belajar siswa predikat $B$ sebesar $65 \%$, sedangkan sebelum diajar dengan menggunakan metode student team learning modification rata-rata hasil belajar siswa predikat B sebesar $90 \%$ dari 31 siswa. Artinya bahwa ada peningkatan perolehan hasil belajar sebelum dan sesudah diajarkan metode student team learning modification.
\end{abstract}

Kata kunci: Student team learning, hasil belajar

\section{Pendahuluan}

Salah satu ilmu pengetahuan dasar yang menunjang ilmu pengetahuan lain dan berkembang sedemikan pesat, baik materi maupun keragamannya adalah fisika. Fisika sebagai salah satu mata pelajaran yang sangat mendukung perkembangan ilmu pengetahuan dan teknologi (IPTEK) dan dekat dengan kehidupan sehari-hari siswa, akan tetapi sebagian siswa masih menganggapnya fisika sebagai salah satu mata pelajaran yang sangat menakutkan, selain membutuhkan teori juga membutuhkan praktek untuk memperkuat pemahaman dan pembuktian konsep. Berdasarkan observasi yang telah dilakukan sebelumnya banyak peserta didik yang beranggapan bahwa fisika itu sulit dan penuh dengan rumus dan perhitungan yang rumit, dikarenakan pembelajaran fisika identik dengan rumus sehingga hanya mengutamakan hafalan baik pada teori maupun rumusnya. Hal ini menjadikan peserta didik sering tidak sanggup dengan metode seperti itu dan menimbulkan rasa kejenuhan yang mengakibatkan kurang fokus dan terdapat rasa enggan untuk belajar fisika. Setiap proses belajar mengajar berlangsung, secara otomatis pihak yang berhubungan langsung didalamnya baik pendidik maupun siswa spontanitas dituntut agar serius. Hal ini disebabkan karena pemikiran seseorang menganggap bahwa suatu materi akan terserap atau terpahami ketika seseorang dalam keadaan serius. Akan tetapi, suatu materi dapat dipahami bukan hanya ketika dalam keadaan serius tetapi juga dapat dilakukan dengan berbagai strategi, cara atau model yang bervariasi. Joice and Well (2009) dalam Rusman (2013: 133) berpendapat bahwa model pembelajaran adalah suatu rencana atau pola yang dapat digunakan untuk membentuk kurikulum (rencana pembelajaran jangka panjang) merancang bahan-bahan pembelajaran, dan membimbing pembelajaran dapat dijadikan pola pilihan, artinya para guru boleh memilih model pembelajaran yang sesuai dan efesien untuk mencapai tujuan pendidikannya. Setiap pendidik sekiranya dapat menciptakan pola atau model pembelajaran yang digunakan dalam pembelajaran fisika agar siswa memiliki ketertarikan pada materi yang diajarkan sehingga pada saat proses pembelajaran berlangsung peserta didik akan aktif dan fokus serta tidak mengalami kejenuhan akibat metode yang monoton. Hamzah (2009: 3) berpendapat bahwa 
dalam model pembelajaran terdapat beberapa strategi, metode dan teknik yang digunakan untuk mencapai tujuan pembelajaran. Strategi pembelajaran adalah cara-cara yang akan digunakan oleh pengajar untuk memilih kegiatan belajar yang akan digunakan selama proses pembelajaran, sedangkan metode pembelajaran adalah jalan yang digunakan guru, yang dapat menjalankan fungsinya sebagai alat untuk mencapai tujuan pembelajaran. Metode pembelajaran lebih bersifat prosedural yaitu berisi tahapan tertentu, sedangkan teknik pembelajaran adalah alat atau media yang digunakan oleh guru untuk mengarahkan kegiatan peserta didik kearah tujuan yang akan dicapai. Dengan memadukan metode pembelajaran yang sesuai dapat menghasilkan peningkatan hasil belajar yang maksimal. Salah satu cara yang dapat dilakukan adalah dengan menciptakan suasana baru dalam ruangan yaitu dengan menggunakan model pembelajaran Student Team Learning Modification. Metode pembelajaran ini berorientasi pada pembelajaran kelompok dan permainan game. Pengambilan model pembelajaran yang bertemakan game dikarenakan banyak siswa yang sangat mencintai dunia games. Jadi diharapkan model pembelajaran ini dapat membawa siswa ke dunia game tetapi sebenarnya tetap berada dalam proses pembelajaran. Berdasarkan uraian di atas, maka peneliti tertarik untuk melakukan penelitian di sekolah mengenai metode pembelajaran yang membuat siswa tidak merasa jenuh, sportif, bertanggung jawab, dan mudah memahami serta dapat menjawab soal fisika dengan cepat dan tepat. Berkenaan dengan hal tersebut maka peneliti memilih judul "Peningkatan Hasil Belajar Dengan Menggunakan Metode Pembelajaran Student Team Learning Modification" dengan rumusan masalah sebagai berikut: 1). Seberapa besar hasil belajar siswa dengan menggunakan metode pembelajaran Student Team Learning Modification? 2). Seberapa besar hasil belajar siswa dengan tidak menggunakan metode pembelajaran Student Team Learning Modification? 3). Apakah terdapat peningkatan hasil belajar siswa setelah diajar dengan menggunakan metode pembelajaran Student Team Learning Modification?

\section{Metode Penelitian}

Jenis penelitian ini adalah penelitian kuantitatif pre eksperimen dengan desain penelitian yaitu Static Group Comparison. Teknik pengambilan sampel pada penelitian ini dengan menggunakan teknik purposive sampling karena yang menjadi sampel dalam penelitian ini adalah 31 siswa. Kelas tersebut dipilih karena memiliki tingkat keseriusan siswa dalam belajar fisika rendah berdasarkan nilai hasil belajar yang diperoleh dari guru mata pelajaran dari ke empat kelas. Untuk mengungkap kebenaran mengenai variabel, peneliti menggunakan lembar observasi keterlaksanaan pembelajaran dan intrumen tes hasil belajar berupa soal pilihan ganda dan essai yang mengukur ranah koginitif siswa dari pengetahuan $(\mathrm{C} 1)$, pemahaman $(\mathrm{C} 2)$ dan aplikasi (C3). Dalam teknik pengumpulan data terdapat dua tahap yaitu tahap persiapan dan tahap pelaksanaan. Untuk tahap persiapan terdiri dari; penyusunan perangkat pembelajaran dan validitas instrumen sedangkan untuk tahap pelaksanaan terdiri dari; memilih sampel, melaksanakan proses pembelajaran, mengobservasi keterlaksanaan pembelajaran dan memberikan tes hasil belajar. Dalam pengolahan data digunakan analisis data hasil validasi perangkat pembelajaran, proses pembelajaran, dan soal tes hasil belajar serta analisis hasil belajar siswa.

\section{Hasil Penelitian dan Pembahasan}

Hasil dan pembahasan penelitian ini adalah sebagai berikut:

\section{Hasil belajar siswa sebelum diajar menggunakan metode Student Team Learning Modification}

Tabel 1. Data hasil belajar fisika siswa tanpa menggunakan metode pembelajaran student team learning modifikasi

\begin{tabular}{cc} 
Parameter & Nilai \\
\hline Nilai Maksimum & 90 \\
\hline Nilai Minimum & 75 \\
\hline Rata-rata & 80,77 \\
\hline Standar Deviasi & 4,37 \\
\hline Varians & 9,11 \\
\hline Koefisien Varians & 5,41
\end{tabular}

Hasil belajar fisika siswa yang tidak diajar dengan metode Student Team Learning Modification 
menunjukkan hasil belajar siswa lebih mendominasi predikat baik (B) dari siswa dengan predikat sangat baik (A). Nilai maksimum yang diperoleh siswa sebelum diajar menggunakan metode Student Team Learning Modification sebesar 92,00. Adapun nilai minimum yang diperoleh sebelum diajar sebesar 75,00. Skor ratarata nilai hasil belajar sebelum diajar menggunakan metode student team learning modifikasi sebesar 80,77 dengan standar deviasi 4,37 dan diperoleh koefisien varians sebesar 5,41. Berdasarkan data yang diperoleh tersebut menunjukkan bahwa metode pengajaran langsung yang digunakan pada saat proses pembelajaran berlangsung telah efektif. Hal ini ditunjukkan oleh perolehan nilai hasil belajar siswa yang rata-rata memperoleh predikat baik (B). Faktor yang mempengaruhi pencapaian perolehan hasil belajar tersebut yaitu tingkat keseriusan siswa pada saat proses pembelajaran berlangsung yang disebabkan oleh rasa keingintahuan siswa terhadap materi pelajaran yang mendorong siswa untuk belajar. Ada beberapa alasan mengapa pendekatan whole class teaching (pengajaran seluruh kelas) atau sering disebut dengan direct interaction (pengajaran langsung) ini ditemukan lebih efektif dibanding pendekatan terindividualisasi. Salah satunya adalah mengajar menggunakan pengajaran langsung memungkinkan guru melakukan kontak dengan masing-masing individu murid dibanding pemberian tugas-tugas individual. Selain itu interaksi antara murid dan guru merupakan aspek krusial dalam proses belajar mengajar yang sukses. Murid juga ditemukan lebih banyak terlibat dalam tugas selama sesi-sesi pengajaran langsung dibanding pengajaran terindividualisasi. ini disebabkan karena lebih mudah bagi guru untuk memantau seluruh kelas sembari mengajar dibanding untuk memantau murid oirang per orang. Pengajaran langsung juga memungkinkan guru untuk mengubah dan membuat variasi kegiatan serta untuk memberikan reaksi yang cepat terhadap tanda-tanda bahwa muridmuridnya mulai "padam", baik melalui tandatanda berkurangnya pemahaman terhadap isi pelajaran yang disampaikan atau melalui tandatanda kebosanan (Muijs dan Reynolds, 2008: 45).

\section{Hasil belajar siswa setelah diajar menggunakan metode Student Team Learning Modication}

Tabel 2. Data hasil belajar fisika dengan menggunakan metode pembelajaran student team learning modifikasi

\begin{tabular}{cc} 
Parameter & Nilai \\
\hline Nilai Maksimum & 87,00 \\
\hline Nilai Minimum & 76,00 \\
\hline Rata-rata & 81,06 \\
\hline Standar Deviasi & 2,84 \\
\hline Varians & 8,12 \\
\hline Koefisien Varians & 3,50
\end{tabular}

Hasil yang diperoleh yaitu nilai hasil belajar tertinggi yang diperoleh siswa setelah dilakukan tes sebesar 87,00. Sedangkan nilai terendah yang diperoleh siswa sebesar 76,00 dengan rata-rata sebesar 81,06. Kategorisasi nilai siswa setelah diajar menggunakan metode Student Team Learning Modification dimana nilai hasil belajar siswa paling banyak berada pada kategori baik (B) sebanyak 28 siswa dari 31 siswa sedangkan selebihnya berada pada kategori sangat baik (A) sebanyak 3 siswa. Berdasarkan hasil analisis deskriptif, pada kelas yang diajar dengan metode Student Team Learning Modification menunjukkan bahwa hasil belajar fisika siswa rata-rata berada pada predikat sangat baik (A) dan baik (B). Hasil belajar fisika siswa yang diajar dengan metode tersebut menunjukkan hasil belajar siswa lebih mendominasi predikat baik (B) dari siswa dengan predikat sangat baik. Nilai maksimum yang diperoleh siswa setelah diajar sebesar 87,00 dan nilai minimum yang diperoleh setelah diajar sebesar 76,00. Skor rata-rata nilai hasil belajar setelah diajar menggunakan metode Student Team Learning Modification sebesar 81,06 dengan standar deviasi 2,84 dan diperoleh koefisien varians sebesar 3,50. Hasil belajar fisika yang diperoleh oleh setiap siswa mengindikasikan keterlakasanaan suatu strategi, model dan metode yang diterapkan pada saat proses pembelajaran berlangsung. Dalam hal ini, model yang digunakan dalam proses pembelajaran adalah model pembelajaran kooperatif dengan menggunakan metode Student Team Learning Modification. Penggunaan model pembelajaran kooperatif selain dapat meningkatkan hubungan sosial yang baik disebabkan anya pembentukan kelompok juga dapat meningkatkan prestasi dan hasil belajar siswa. Hal ini sejalan dengan teori yang dikemukakan oleh para ahli kognisi. 
Perspektif kognitif berpandangan bahwa interaksi antarsiswa akan meningkatkan prestasi belajar mereka mampu memproses informasi secara mental (pikiran/kognisi) daripada secara motivasional (Huda, 2015: 39).

\section{Peningkatan hasil belajar setelah diajar menggunakan metode student team learning modifikasi}

Berdasarkan data yang telah diperoleh yaitu antara nilai hasil belajar siswa sebelum dan sesudah diajar dengan menggunakan metode Student Team Learning Modification terdapat perbedaan hasil belajar fisika antara siswa yang diajar dengan metode Student Team Learning Modification dan siswa yang diajar dengan pembelajaran langsung modifikasi. Hal ini berdasarkan pada nilai rata-rata dan standar deviasi yang diperoleh pada hasil belajar siswa sebelum dan sesudah diajar dengan menggunakan metode Student Team Learning Modification. Telah dijelaskan sebelumnya bahwa nilai ratarata hasil belajar fisika yang diperoleh tersebut pada dasarnya memiliki perbedaan dan rata-rata nilai hasil belajar siswa dikategorikan pada predikat baik (B). Berdasarkan hal tersebut metode pembelajaran student team learning modification yang telah diterapkan di dalam kelas, dapat mengubah nilai rata-rata yang diperoleh siswa. Hal ini ditinjau dari hasil uji gain (uji beda) yang telah dilakukan menunjukkan bahwa terdapat perbedaan perolehan hasil belajar siswa antara sebelum dan sesudah menggunakan metode Student Team Learning Modification sebesar 0,03. Jika disesuaikan dengan tabel kriteria gain ternormalisasi maka peningkatan hasil belajar yang diperoleh tidak signifikan disebabkan berada pada taraf rendah karena nilai gain yang diperoleh lebih kecil dari 0,3 yang merupakan ketentuan nilai standar pada uji gain (uji beda). Dengan menerapkan metode student team learning modification di dalam kelas sebagai upaya meningkatkan hasil belajar siswa selain menggunakan metode konvensional atau ceramah telah menunjukkan bahwa terdapat ketertarikan siswa terhadap metode baru yang diterapkan. Hal ini terlihat oleh hasil belajar yang diperoleh siswa yaitu adanya peningkatan antara sebelum dan sesudah menggunakan metode Student Team Learning Modification. Meskipun peningkatan yang terjadi tidak signifikan dikarenakan berada pada pada taraf rendah, hal ini telah menunjukkan bahwa metode yang digunakan telah efektif. Perbedaan perolehan hasil belajar antara sebelum dan sesudah menggunakan metode yang diterapkan tidak signifikan peningkatannya, hal dapat disebabkan oleh beberapa hal, seperti hanya terdapat beberapa siswa yang antusias mengikuti pembelajaran pada saat metode pembelajaran Student Team Learning Modification diterapkan, metode yang digunakan masih dianggap asing oleh siswa sehingga sulit untuk menyesuaikan dengan metode yang sering digunakan sebelumnya seperti metode ceramah, dan sintaks atau tahap-tahap metode pembelajaran Student Team Learning Modification ini terasa agak sulit serta kurangnya pemahaman siswa mengenai materi pelajaran yang digunakan dalam pembelajaran ini sehingga berpengaruh pada hasil belajar yang diperoleh oleh siswa. Sebagaimana dalam penelitian sebelumnya yang dilakukan oleh Itiqamah (2013) yang menunjukkan bahwa tidak adanya perbedaan yang signifikan hasil belajar fisika siswa yang diajar dengan menggunakan metode Hands On Activity dengan siswa yang tidak diajar Hands On Activity dipengaruhi oleh beberapa faktor diantaranya yaitu karakter siswa yang mencakup minat, kedisiplinan dalam mengikuti proses pembelajaran, waktu pembelajaran yang tidak efisien, dan kesesuaian metode dengan peserta didik, sehingga memerlukan banyak waktu supaya peserta didik mampu membiasakan diri dan mampu merubah minat yang tadinya sangatlah kurang akan menjadi peserta didik yang memiliki minat lebih tinggi. Selain dalam proses pembelajaran, hal yang berpengaruh adalah kesiapan siswa sebelum mengikuti tes hasil belajar. Ditinjau dari segi kesiapan banyak siswa yang mengaku bahwa tidak belajar atau kesiapan mereka sangatlah kurang. Padahal sudah ada pemberitahuan sebelumnya. Bagaimanapun kemampuan seseorang, ketika pelajaran itu tidak diulang maka akan sangat berpengaruh pada hasil belajarnya. Hal ini juga ditegaskan dengan pendapat yang menyatakan bahwa variasi personal juga salah satu faktor yang mempengaruhi penelitian eksperimen yaitu variasi karakteristik individu sepanjang waktu. Walaupun secara umum karakteristik seseorang cenderung stabil, namun beberapa karakteristik seseorang cenderung stabil, namun beberapa karakteristik seseorang 
cenderung berubah paa waktu tertentu (Seniati, 2009: 81). Setiap metode pembelajaran memiliki kelebihan dan kekurangan dalam proses penerapannya. Pada metode student Team Learning Modification ini memiliki kelebihan seperti tahap atau sintaks metode ini disusun sesuai dengan permainan sistem gugur sehingga menciptakan suasana bermain didalam kelas namun tetap dalam proses pembelajaran formal sehingga siswa tidak merasa tegang pada saat belajar. Selain itu dengan menggunakan metode ini dapat meningkatkan kerjasama dan sifat toleransi serta saling memberikan dorongan untuk mengetahui suatu hal antar siswa dalam tiap kelompok dan melatih jiwa sportifitas antar kelompok dalam menyelesaikan tugas yang diberikan. Setiap kelebihan yang dimiliki oleh suatu metode pembelajaran tentu juga memiliki kekurangan, seperti halnya dalam metode student team learning modifikasi ini. Metode ini memiliki kekurangan yaitu agak rumitnya sintaks atau tahapan yang disediakan oleh metode ini sehingga siswa belum siap untuk menggunakannya dalam waktu yang minim. Pada penelitian yang telah dilakukan dengan menggunakan metode Student Team Learning Modification dengan meninjau nilai hasil belajar sebelumnya yang dilakukan oleh guru mata pelajaran fisika pada kelas tersebut dan nilai hasil belajar yang diperoleh setelah diajar menggunakan metode Student Team Learning Modification telah terjadi peningkatan meskipun tidak adanya perbedaan yang signifikan hasil belajar fisika siswa yang diajar dan tanpa diajar menggunakan metode Student Team Learning Modification yang dipengaruhi oleh beberapa faktor dan sejalan dengan peneliti sebelumnya.

\section{Kesimpulan}

Berdasarkan penelitian yang telah dilakukan, adapun kesimpulan yang dipaparkan sebagai berikut:

1. Hasil belajar fisika siswa yang diajar dengan metode Student Team Learning Modification yaitu dilihat dari analisis deskriptif rata-rata perolehan hasil belajar siswa dikategorikan dengan predikat baik dengan skor rata-rata 81,06 .

2. Hasil belajar fisika siswa yang diajar tanpa menggunakan metode pembelajaran Student Team Learning Modification dilihat dari analisis deskriptif rata-rata perolehan hasil belajar siswa dikategorikan dengan predikat baik dengan skor rata-rata 80,77.

3. Terdapat peningkatan hasil belajar fisika antara siswa yang diajar dan tanpa diajar menggunakan metode Student Team Learning Modification.

\section{Daftar pustaka}

Abdi, Istiqamah. 2016. Efektivitas Penggunaan Metode Hands On Activity Terhadap Hasil Belajar Fisika Kelas X SMAN 1 Bontonompo Pada Materi Hukum Newton. Makassar: UIN Alauddin.

Arends, Richard I. 2008. Learning To Teach: Belajar Untuk Mengajar. Yogyakarta: Pustaka Pelajar.

Huda, Miftahul. 2015. Cooperative Learning. Yogyakarta: Pustaka Belajar.

Seniati, Liche dkk. 2009. Psikologi Eksperimen. Indonesia: Macana Jaya Cemerlang.

Hamzah, B. 2009. Model Pembelajaran. Jakarta: Bumi Aksara.

Rusman. 2013. Model-Model Pembelajaran. Jakarta: Raja Grafindo Persada. 